\title{
INSIDERS' PROFITS, COSTS OF TRADING, AND MARKET EFFICIENCY*
}

\author{
H. Nejat SEYHUN
}

The University of Michigan, Ann Arbor, MI 48109, USA

\author{
Received November 1984, final version received October 1985
}

This study investigates the anomalous findings of the previous insider trading studies that any investor can earn abnormal profits by reading the Official Summary. Availability of abnormal profits to insiders, availability of abnormal profits to outsiders who imitate insiders, determinants of insiders' predictive ability, and effect of insider trading on costs of trading for other investors are examined by using approximately 60,000 insider sale and purchase transactions from 1975 to 1981. Implications for market efficiency and evaluation of abnormal profits to active trading strategies are discussed.

\section{Introduction}

Numerous studies, such as Lorie and Niederhoffer (1968), Pratt and DeVere (1970), Jaffe (1974), and Finnerty (1976) among others, conclude that insiders earn significant abnormal profits by trading the securities of their own firms. ${ }^{1}$ Estimates of insiders' abnormal profits in these studies vary from $3 \%$ to $30 \%$ during holding periods of eight months to three years. Surprisingly, insider trading studies also report that even uninformed outsiders can earn significant abnormal profits by imitating insiders: Outsiders can purchase stock following insiders' stock purchases, sell stock following insiders' stock sales using publicly available insider trading information, and thereby also earn $3 \%$ to $30 \%$ abnormal profits.

The conclusion that abnormal profits can be earned by trading on the basis of publicly available information contradicts the efficient markets hypothesis which maintains that security prices respond rapidly to public information,

\footnotetext{
* This paper is based on a Ph.D. dissertation written at the University of Rochester. I am grateful to my dissertation committee, G. William Schwert (chairman), Clifford W. Smith, and Jerold B. Warner for their guidance and encouragement. Helpful comments were received from Michael Bradley, Susan Chaplinsky, Eugene Fama, Michael Jensen, Han Kim, Richard Leftwich, Wayne Mikkelson, Jay Ritter, and an anonymous referee.

'Individuals who are officers, directors, and owners of $10 \%$ or more of any equity class of securities are defined as insiders by the Securities and Exchange Act of 1934.
} 
thus precluding any systematic profit opportunities. The efficient markets hypothesis is a central tenet of financial economics and it is supported by a large body of evidence. ${ }^{2}$ This study reinvestigates stock price behavior following insiders' transactions and attempts to reconcile the efficient markets hypothesis with the previously reported availability of abnormal profits to outsiders.

Recent studies by Banz (1981) and Reinganum (1981) document that the use of the Capital Asset Pricing Model results in potential biases in measuring expected returns to securities. Consequently, the results of the previous insider trading studies using the CAPM must be interpreted with caution. The methodology used in this study avoids this bias. Furthermore, previous insider trading studies generally assume that all insider trading information becomes publicly available within two months. This assumption can lead to a potential bias against market efficiency: In efficient markets, stock price reaction is expected to occur at the time information becomes public. If some transactions are published with a more than two month delay, then the stock price reaction is also expected to occur with a more than two month delay. To evaluate the abnormal returns available to outsiders, this study uses the actual dates insiders first report their transactions to the Securities and Exchange Commission (SEC) and the dates insider trading information is published in the Official Summary. The profitability of insider trading is evaluated by examining approximately 60,000 insider transactions during the period 1975 to 1981 . The data are analyzed separately for buy and sell decisions, type of insiders, and dollar volume of insider trading.

A generally overlooked implication of profitable trading by informed investors is that there is a loser for each winner, since informed traders' abnormal profits reduce the opposing traders' realized returns dollar for dollar. An investor who attempts to exploit a perceived profit opportunity must also bear the risk of potential losses to opposing informed traders. If the informed traders impose significant losses on the opposing uninformed traders, then ignoring informed traders' abnormal profits can lead to an overstatement of the realizable abnormal returns to any trading rule.

The significance of the costs imposed by the informed traders on the uninformed traders has not been empirically examined, since the informed traders' abnormal profits are not readily observable. Studies by Glosten and Milgrom (1985), Copeland and Galai (1983), Treynor (1981), and Bagehot (1971) hypothesize a positive relation between the informed traders' abnormal profits and the bid-ask spread in that security. Profitable trading by informed traders imposes abnormal losses on all opposing traders, including the market-maker. Consequently, the market-maker is forced to charge a higher

\footnotetext{
${ }^{2}$ See Fama (1970) for a review of theory and early evidence on the efficient markets hypothesis.
} 
bid-ask spread to all traders to help offset his systematic losses to informed traders. In this study, the significance of the uninformed traders' expected losses to the informed traders is investigated by examining the relation between the bid-ask spread and insiders' abnormal profits.

The paper is organized as follows: Section 2 discusses the relation between profitable trading by informed traders and the bid-ask spread. The insider trading data and the sample characteristics are discussed in section 3 . Section 4 explains the empirical methodology, and section 5 presents the results. Conclusions and implications are in section 6.

\section{Informed traders' abnormal profits and bid-ask spread}

If some traders are better informed than others, then the market-maker in a security experiences an adverse selection problem. If he were to set a single price to buy and sell any amount of securities on demand, on average, he would neither gain from nor lose to uninformed investors, since trading by uninformed investors is not related to abnormal future stock price movements by definition. However, he would systematically lose to the informed traders. He would inadvertently buy stock from the informed traders prior to abnormal stock price declines and sell stock to the informed traders prior to abnormal stock price increases, thereby resulting in inventory positions that are negatively correlated with future abnormal stock price movements. In effect, the informed traders' abnormal profits would come at the market-maker's expense.

If the market-maker cannot distinguish the informed traders from the uninformed traders prior to trading, then he would be forced to charge all traders for the expected value of their possible non-public information. He would lower his bid (purchase) price to reflect possible unfavorable information and raise his ask (sale) price to reflect possible favorable information of the informed traders. The informed traders would still purchase stock from the market-maker if they expect the stock price to rise above the ask price, or sell stock to the market-maker if they expect the stock price to fall below the bid price. Therefore, even with a positive bid-ask spread, the market-maker continues to incur net losses to the informed traders. However, his losses to the informed traders are now offset by his gains from the uninformed traders, who now pay a higher bid-ask spread to trade with the market-maker. A higher bid-ask spread means that the expected traders' abnormal profits come at the expense of the uninformed traders who trade for reasons other than profiting from information.

The market-maker's response to informed traders implies a positive relation between the bid-ask spread and the informed traders' abnormal profits. The bid-ask spread would be higher than otherwise, if the informed traders possess more valuable information when they trade or account for a greater proportion 
of the overall trading volume. ${ }^{3}$ In effect, the market-maker's bid-ask spread reflects his expected losses to all informed traders.

Ignoring the relation between the bid-ask spread and the expected loss to informed traders can lead to an overstatement of the realizable return to any active trading rule. If it is assumed that investors can always trade at the current stock price without ever paying the bid-ask spread, then their realizable return will be overstated by an amount equal to their expected loss to informed traders. This study provides the first empirical test of the hypothesized positive relation between the bid-ask spread and the expected loss to informed traders. If the evidence indicates a significant positive relation between the bid-ask spread and the expected loss to informed traders, then an allowance for the expected loss to informed traders can be made by including the bid-ask spread for a 100-share transaction as an additional cost of trading. The bid-ask spread for a 100-share transaction would overestimate the expected loss to informed traders to the extent that it reflects other costs of market-making. However, if the informed investors trade larger volumes of stock to exploit more valuable information, then the bid-ask spread for a 100-share transaction can also underestimate the expected loss to informed traders from their larger volume transactions.

\section{Data and sample characteristics}

The insider trading data used in this study come from a computer tape compiled by the Securities and Exchange Commission (SEC). The tape summarizes more than 1.5 million insider transactions in all publicly held firms from 1975 to 1981 . This study analyzes a sample of transactions in 790 firms on the daily returns file of the Center for Research in Security Prices (CRSP). The 190 firms listed on option exchanges on January 1, 1977 are included in the sample. The remaining 600 firms are chosen by stratified random sampling based on the size of firms' equity. Out of 790 firms, 21 did not report any insider trading between 1975 and 1981. Consequently, the actual number of firms analyzed is 769 .

Table 1, panel A shows a breakdown of tho insider trading sample by firm size. The sample analyzed in this study contains a total of 59,148 open market sales and purchases. ${ }^{4}$ Total dollar value of insiders' transactions exceeds $\$ 11$ billion, 58\% of which occurs in the largest firm size group. Panel B shows a

\footnotetext{
${ }^{3}$ Other factors that can affect the size of the bid-ask spread, such as the competition facing the market-maker or costs of maintaining inventorics, are analyzed in Demsetz (1968), Tinic (1972), Tinic and West (1972), Benston and Hagerman (1974), Stoll (1978), and Amihud and Mendelson (1980) among others.

${ }^{4}$ Numerous consistency checks on dates, prices, and shares were performed to eliminate approximately 1000 transactions containing apparent data errors. Also, transactions involving less than 100 shares are excluded.
} 
Table 1

Distribution of the number of firms, dollar value, and number of transactions, grouped by the average size of equity of the firm and the identity of insiders (dollar figures are in $\$$ million). Sample period is from 1975 to 1981.

\begin{tabular}{|c|c|c|c|c|c|c|}
\hline \multicolumn{7}{|c|}{ Panel A: Grouping by firm size } \\
\hline & $\begin{array}{c}\text { Less } \\
\text { than } \$ 25 \\
\text { milllion }\end{array}$ & $\begin{array}{l}\text { Between } \\
\$ 25 \text { and } \\
\$ 50 \\
\text { million }\end{array}$ & $\begin{array}{l}\text { Between } \\
\$ 50 \text { and } \\
\$ 250 \\
\text { million }\end{array}$ & $\begin{array}{l}\text { Between } \\
\$ 250 \\
\text { million } \\
\text { and } \\
\$ 1 \text { billion }\end{array}$ & $\begin{array}{l}\text { More } \\
\text { than } \$ 1 \\
\text { billion }\end{array}$ & $\begin{array}{c}\text { All } \\
\text { finms }\end{array}$ \\
\hline $\begin{array}{l}\text { Number } \\
\text { of firms }\end{array}$ & 104 & 68 & 173 & 267 & 157 & 769 \\
\hline $\begin{array}{l}\text { Total dollar } \\
\text { value of } \\
\text { transactions }\end{array}$ & $\$ 152$ & $\$ 182$ & $\$ 1,287$ & $\$ 2,990$ & $\$ 6,490$ & $\$ 11,101$ \\
\hline $\begin{array}{l}\text { Number of } \\
\text { transactions }\end{array}$ & 4,141 & 3,010 & 10,552 & 23,267 & 18,178 & 59,148 \\
\hline $\begin{array}{l}\text { Ratio of } \\
\text { purchases } \\
\text { to sales }\end{array}$ & 2.09 & 1.27 & 0.79 & 0.57 & 0.59 & 0.70 \\
\hline \multicolumn{7}{|c|}{ Panel B: Grouping by identity of insiders } \\
\hline & Officers & Directors & $\begin{array}{l}\text { Officer- } \\
\text { directors }\end{array}$ & $\begin{array}{l}\text { Chairmen } \\
\text { of boards of } \\
\text { directors }\end{array}$ & $\begin{array}{l}\text { Large } \\
\text { share- } \\
\text { holders }\end{array}$ & $\begin{array}{c}\text { All } \\
\text { insiders }\end{array}$ \\
\hline $\begin{array}{l}\text { Total dollar } \\
\text { value of } \\
\text { transactions }\end{array}$ & $\$ 806$ & $\$ 1,889$ & $\$ 571$ & $\$ 408$ & $\$ 7,427$ & $\$ 11,101$ \\
\hline $\begin{array}{l}\text { Number of } \\
\text { transactions }\end{array}$ & 21,913 & 17,486 & 6,520 & 3,400 & 9,829 & 59,148 \\
\hline
\end{tabular}

breakdown of the insider trading sample by the identity of insiders: officers, directors, officer-directors, chairmen of the boards of directors, and large shareholders. Officers trade most frequently, followed by directors, large shareholders, officer-directors, and chairmen of the boards of directors. The large shareholder group also trades the largest dollar volume of stock, accounting for $67 \%$ of the overall dollar volume of trading.

\section{Empirical methodology}

\subsection{Benchmark selection}

Among the recent insider trading studies, Jaffe (1974) and Finnerty (1976) use variants of the Capital Asset Pricing Model (CAPM) to estimate abnormal 
returns to securities. Work by Banz (1981) and Reinganum (1981) shows that the CAPM based residuals are on average positive for small firms, and negative for large firms. This systematic bias in CAPM residuals can lead to biases in estimating abnormal returns in insider trading studies. If insiders have predominantly more purchases than sales in small firms, then the positive CAPM residuals in small firms will be associated with insider purchases. Similarly, if insiders have predominantly more sales than purchases in large firms, then the negative CAPM residuals in large firms will be associated with insider sales.

Table 1 shows the ratio of insiders' stock purchases to sales for different size firms. In small firms, insiders have approximately twice as many purchases as sales. In large firms, the ratio of insiders' purchases to sales falls to about 0.6. This evidence suggests that even if insider trading conveys no information, biases in the CAPM can indeed result in finding positive abnormal returns following insider purchases and negative abnormal returns following insider sales. Consequently, the conclusions of the previous insider trading studies using the CAPM benchmark may overstate the abnormal returns realized from insider trading.

This study uses the market-model to measure the expected returns to securities. The market-model is a statistical model based on the joint normality of the distribution of security returns. Given parameter stationarity, the market-model prediction errors have an expected value of zero for firms of any size, thereby avoiding the bias introduced by CAPM.

\subsection{Abnormal returns and significance tests}

Based on the market-model, the prediction error $P E_{i, t}$ for security $i$ on day $t$, from 199 days before to 300 days after each event day is calculated as follows: ${ }^{5}$

$$
P E_{i, t}=\left(r_{i, t}-\left(\hat{\alpha}_{i}+\hat{\beta}_{i} r_{m, t}\right)\right) W \text { for } t=-199,300,
$$

where $r_{i, t}$ is the with-dividend return to security $i$ on day $t$, and $r_{m, t}$ is the with-dividend return to value-weighted portfolio of all New York Stock Exchange and American Stock Exchange stocks on day $t$. To account for potential changes in market parameters, two sets of parameters $\hat{\alpha}_{i}$ and $\hat{\beta}_{i}$ are estimated using ordinary least squares regression of $r_{i, t}$ on $r_{m, t}$ with 250 pre-event and 250 post-event daily return data, always excluding the period from 199 days before to 300 days after the event day. The pre-event estimates are used to calculate the prediction errors between days -199 and -1 , and post-event estimates are used to calculate the prediction errors between days 0 and 300. The last insider trading day in each month is taken as the event day. The parameter $W$ is equal to one if the number of buyers exceed the number

\footnotetext{
${ }^{5}$ See Fama (1976, ch. 4) for a discussion of the market-model. The event study methodology is pioneered by Fama, Fisher, Jensen and Roll (1969).
} 
of sellers in that month, or minus onc if the number of sellers excced the number of buyers. If the number of buyers equals the number of sellers, that month is excluded. An insider is considered a buyer if he buys more shares than he sells or a seller if he sells more shares than he buys. Insiders who buy as many shares as they sell are ignored.

Successive, non-overlapping one-month and two-month periods are used to classify insiders' transactions. The overall results are similar and only twomonth period results are reported. The two-month period results are chosen for extensive analysis to economize on data processing costs.

The average portfolio prediction error for event day $t, A P E_{t}$, is calculated by averaging all prediction errors for that event day. This test statistic incorporates any possible cross-sectional dependencies of prediction errors at a given calendar day,

$$
A P E_{t}=\frac{1}{K_{t}} \sum_{i=1}^{K_{t}} P E_{i, t} \text { for } t=-199,300,
$$

where $K_{t}$ is the number of prediction errors on event day $t$.

The significance of the average portfolio prediction errors is measured by standardizing the average portfolio prediction errors by their sample standard error $\hat{\sigma}(A P E)$,

$$
t\left(A P E_{t}\right)=A P E_{t} / \hat{\sigma}(A P E) .
$$

The sample standard error of $A P E_{t}, \hat{\sigma}(A P E)$, is calculated from 199 days before to 300 days after the event day, by taking into account the serial correlation of the $A P E_{t}$ 's. Empirical examination of the $A P E$ series shows a stationary, third-order autoregressive process. Thus,

$$
A P E_{t}=\delta+\phi_{1} A P E_{t-1}+\phi_{2} A P E_{t-2}+\phi_{3} A P E_{t-3}+u_{t} .
$$

The standard error of the $A P E$ series, $\hat{\sigma}(A P E)$, is computed by solving the Yule-Walker equations corresponding to eq. (4). ${ }^{6}$ The $t$-statistic in eq. (3) has a Student- $t$ distribution with 493 degrees of freedom when $A P E_{t}$ is a stationary normal process. The cumulative daily average prediction error from event day $t_{1}$ to event day $t_{2}, \operatorname{CAPE}\left(t_{1}, t_{2}\right)$, is calculated by summing the daily average prediction errors,

$$
\text { CAPE }\left(t_{1}, t_{2}\right)=\sum_{t=t_{1}}^{t_{2}} A P E_{t} .
$$

The significance of the cumulative daily average prediction error is measured

\footnotetext{
${ }^{6}$ For a discussion of autoregressive processes, see Nelson (1973). For the overall sample, the partial autocorrelation coefficients of the $A P E_{l}$ in eq. (4) are 0.38 ( $t$-statistic 8.4) at first lag, 0.16 ( $t$-statistic 3.5) at second lag, and $0.10(t$-statistic 2.2$)$ at third lag.
} 
by standardizing each cumulative daily average prediction error by its sample standard error, ${ }^{7}$

$$
t\left(\operatorname{CAPE}\left(t_{1}, t_{2}\right)\right)=\operatorname{CAPE}\left(t_{1}, t_{2}\right) / \hat{\sigma}\left(\operatorname{CAPE}\left(t_{1}, t_{2}\right)\right) .
$$

\section{Empirical results}

\subsection{Profitability of insider trading}

The cumulative daily average prediction errors are plotted separately for sales and purchases in fig. 1 . The cumulative daily average prediction errors and their $t$-statistics computed from eq. (5) and (6), respectively, are shown in table 2. For the overall sample, the prediction errors for sales are multiplied by minus one before averaging with purchases. Consequently, abnormal stock price rises following insiders' purchases and abnormal stock price declines following insiders' sales are measured as positive abnormal returns in the overall sample.

If insiders purchase stock prior to an announcement of favorable information, then insiders' purchases will be followed by positive abnormal returns. If insiders also refrain from purchasing stock until after unfavorable information is announced, then insiders' purchases will be preceded by negative abnormal returns. Similar considerations hold for insiders' sale transactions. Table 2 shows that, during the 100 days following the insider trading day, stock prices rise abnormally by $3.0 \%$ ( $t$-statistic 4.4 ) for purchases and decline abnormally by $1.7 \%$ ( $t$-statistic -2.7 ) for sales. This suggests that insiders purchase stock prior to the release of favorable information and sell stock prior to the release of unfavorable information. ${ }^{8}$ During the 100 days prior to the insider trading day, stock prices decline abnormally by $1.4 \%$ ( $t$-statistic -2.1 ) for purchases and rise abnormally by $2.5 \%$ ( $t$-statistic 4.0 ) for sales. This suggests that insiders also tend to refrain from purchasing stock until after unfavorable information is released, and from selling stock until after favorable information is released. Fig. 1 indicates that most of the abnormal stock price adjustment occurs during the 100 days following the insider trading day. For the overall sample, the stock price adjustment between days 101 and 300 is $0.8 \%$ ( $t$-statistic 0.9 ), which is insignificantly different from zero.

${ }^{7}$ The standard error of the cumulative daily average prediction error, $\hat{\sigma}\left(C A P E\left(t_{1}, t_{2}\right)\right)$, is calculated from the general formula for the variance of a sum,

$$
\hat{\sigma}\left(\operatorname{CAPE}\left(t_{1}, t_{2}\right)\right)=\left[\sum_{j=t_{1}}^{t_{2}} \sum_{k=t_{1}}^{t_{2}} \operatorname{cov}\left(A P E_{j}, A P E_{k}\right)\right]^{1 / 2},
$$

where the covariances of the $A P E$ are computed from the Yule-Walker equations corresponding to eq. (4).

${ }^{8}$ During the first 40 days following the insider trading day, stock prices rise abnormally for $55 \%$ of the purchases and only $45 \%$ of the sales. The $t$-statistics for the hypothesis that the true proportions are $50 \%$ are 7.5 for purchases and -9.4 for sales. 


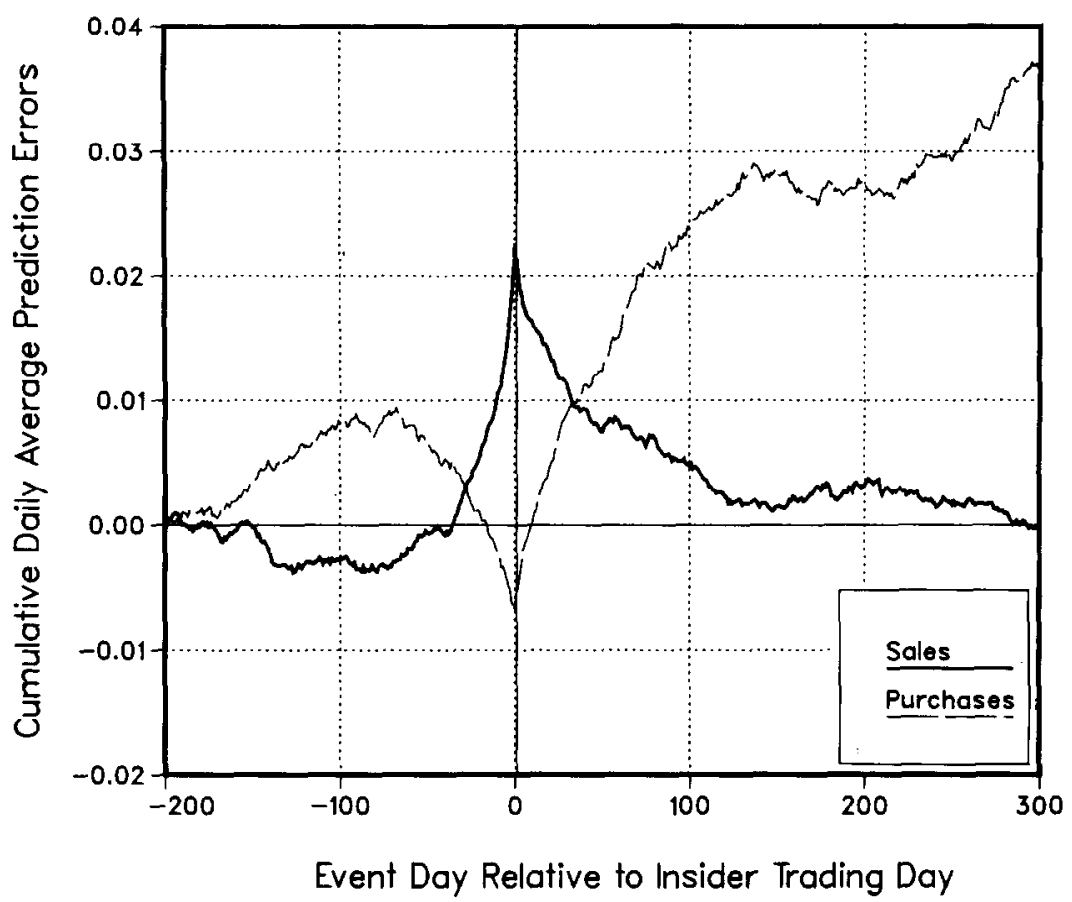

Fig. 1. Cumulative daily average prediction errors from 199 days before to 300 days after the insider trading day, for a portfolio of 769 firms traded by insiders during 1975 to 1981, separated by sale and purchase transactions.

Insiders' abnormal profits do not appear to be especially large. However, insider trading is regulated by the Securities and Exchange Act of 1934. Insiders can be sued for violating their fiduciary responsibilities to their shareholders if they trade on material non-public information prior to the public announcement of the information. ${ }^{9}$ Consequently, insiders would not be expected to trade for their own account immediately prior to highly profitable but also publicized corporate events such as mergers and tender offers.

Estimates of insiders' abnormal profits presented in table 2 are smaller than the estimates in the previous insider trading studies. For example, Jaffe (1974) estimates insiders' gross abnormal profits to be $2 \%$ over two months and 5\%

\footnotetext{
${ }^{9}$ Section 10 of the Securities and Exchange Act of 1934 prohibits fraud in purchase or sale of securities. Section 16(a) requires the reporting of insiders' transactions. Section 16(b) requires the profits from purchases and sales within six months of cach other to be returned to the corporation. Section 16(c) prohibits short sales by insiders. Section 32 as amended in 1975 provides penalties up to $\$ 10,000$ fine and five years of imprisonment for violating any provision of the securities law.
} 
Table 2

Percentage cumulative daily average prediction errors, $C A P E$, and their $t$-statistics in parentheses, for 769 firms traded by insiders from 1975 to 1981 for selected periods around the insider trading day, denoted as day 0 .

\begin{tabular}{lrcc}
\hline Event period & $\begin{array}{c}\text { CAPE for } \\
\text { overall } \\
\text { sample }\end{array}$ & $\begin{array}{c}\text { CAPE } \\
\text { for } \\
\text { purchases }\end{array}$ & $\begin{array}{c}\text { CAPE } \\
\text { for } \\
\text { salcs }\end{array}$ \\
\hline $\begin{array}{l}\text { Day - 100 } \\
\text { through 0 }\end{array}$ & -2.1 & -1.4 & 2.5 \\
Day - 20 & $(-3.3)$ & $(-2.1)$ & $(4.0)$ \\
through 0 & -1.3 & -0.7 & 1.7 \\
Day 1 & $(-4.8)$ & $(-2.4)$ & $(6.2)$ \\
through 20 & 1.0 & 1.1 & -0.9 \\
Day 1 & $(3.7)$ & $(3.8)$ & $(-3.3)$ \\
through 50 & 1.6 & 1.9 & -1.5 \\
Day 1 & $(3.6)$ & $(4.0)$ & $-3.4)$ \\
through 100 & 2.3 & 3.0 & -1.7 \\
Day 101 & $(3.7)$ & $(4.4)$ & -0.5 \\
through 300 & 0.8 & 1.3 & $(-0.6)$ \\
Day 1 & $(0.9)$ & $(1.4)$ & -2.2 \\
through 300 & 3.1 & 4.3 & $(-2.0)$ \\
Sample size & $(2.8)$ & $(3.7)$ & 8,839
\end{tabular}

over eight months following intensive trading periods. An outsider who imitates insiders with a two-month delay also earns $5 \%$ over the next eight months. This implies that Jaffe finds $7 \%$ abnormal returns over a ten-month period. Finnerty (1976) finds between $4.8 \%$ and $8.3 \%$ abnormal returns over an eleven-month period. Pratt and DeVere (1970) examine the returns to firms purchased by three or more insiders and sold by none, and firms sold by three or more insiders and purchased by none. Pratt and DeVere find that firms purchased outperform firms sold by $17.5 \%$ after one year, $28.6 \%$ after two years, and $32.4 \%$ after three years.

In an attempt to reconcile the differences with the previous studies, the tests in table 2 are replicated using different models of expected returns, different estimating periods, and different classification criterion for insiders. As alternative benchmark models, the Scholes and Williams (1977) estimates of the market-model parameters, the mean-returns adjusted model, and the Sharpe-Lintner version of the CAPM are used. The results based on the Scholes-Williams model and the mean-returns adjusted model agree closely with the market-model which suggests that the results are not sensitive to a particular measure of expected returns. The results using only the 
pre-event periods to estimate expected returns to securities are similar to fig. 1 . Using dollar volume of insider sales and purchases instead of number of insiders to classify a given month as a purchase or sale month also gives similar results. Classifying insider trading months on the basis of the net number of insiders (calculated as the absolute value of purchasers minus sellers in each month) does not reveal significant differences in abnormal returns to insiders.

In contrast, using the CAPM benchmark to measure the expected returns to securities increases the measured abnormal returns during the 300 days following the insider trading day from $3.1 \%$ to $4.3 \%$. This evidence is consistent with the upward bias in CAPM based abnormal returns. The exact magnitude of the bias due to CAPM during other time periods would depend on the strength of the small firm effect and the distribution of the sale and purchase transactions across firms. Also, using the period immediately prior to the insider trading day to estimate the market-model parameters increases the measured abnormal returns from $3.1 \%$ up to about $7 \%$. This is not surprising since fig. 1 indicates that using the period immediately prior to the insider trading day would cause estimates of expected returns to be downward biased for purchases and upward biased for sales. These tests suggest that the failure of the CAPM to properly measure expected returns, as well as inappropriate choice of estimation periods, can result in larger estimates of abnormal profits following insider transactions.

\subsection{Bid-ask spread and expected loss to insiders}

As discussed earlier, the market-maker's response to profitable trading by informed traders is to raise the bid-ask spread. Recent studies by Schultz (1983) and Stoll and Whaley (1983) show that there is a negative monotonic relation between firm size and the bid-ask spread. For small firms (average equity value of $\$ 3.4$ million), Schultz estimates the bid-ask spread plus the commission fee to be $11.4 \%$. Stoll and Whaley estimate that the bid-ask spread falls from $2.9 \%$ to $0.7 \%$ as firm size increases from about $\$ 15$ million to more than $\$ 3$ billion. Consequently, the hypothesized positive relation between the bid-ask spread and expected loss to insiders implies a negative relation between the firm size and expected loss to insiders. Fixed costs of market-making combined with lower trading volume in small firms also implies larger bid-ask spreads in small firms. However, if the fixed cost of market-making is largely responsible for differences in bid-ask spreads across firms, then no relation between firm size and expected loss to informed traders would be expected.

The relation between the firm size and expected losses to insiders is investigated by using regression analysis. Including insider transactions from successive calendar months induces autocorrelation of the residuals which is taken 
Table 3

Generalized least squares regression of the cumulative daily average prediction errors, and ordinary least squares regression of the probability of trading against insiders, on the average size of the equity of the firm. ${ }^{2}$ The $t$-statistics for the estimated coefficients are shown in parentheses. Sample period is from 1975 to 1981.

\begin{tabular}{|c|c|c|c|}
\hline $\begin{array}{l}\text { Model } \\
\text { number }\end{array}$ & Model & $\begin{array}{l}\text { Sample } \\
\text { size }\end{array}$ & $\begin{array}{c}F- \\
\text { statistics }\end{array}$ \\
\hline (1) & $\begin{aligned} C A P E(1,50)= & 0.130-0.0057 L V \\
& (8.3)(-7.4)\end{aligned}$ & 15,083 & $54.0^{\mathrm{b}}$ \\
\hline (2) & 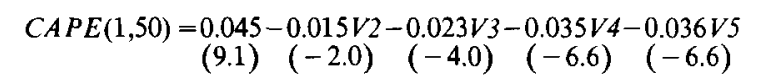 & 15,083 & $15.5^{\mathrm{b}}$ \\
\hline (3) & $\begin{aligned} C A P E(1,100)= & 0.200-0.0092 L \mathrm{~V} \\
& (8.1) \quad(-7.3)\end{aligned}$ & 15,083 & $53.0^{\mathrm{b}}$ \\
\hline (4) & $\begin{aligned} C A P E(1,100)= & 0.070-0.021 \mathrm{~V} 2-0.041 \mathrm{V3}-0.056 \mathrm{VA}-0.058 \mathrm{~V} 5 \\
& (7.2)(-1.7)(-4.4)(-6.7)(-6.6)\end{aligned}$ & 15,083 & $15.5^{\mathrm{b}}$ \\
\hline (5) & $\begin{aligned} \text { Probability }= & 0.122-0.0054 L V \\
(6.0) & (-5.2)\end{aligned}$ & 769 & $26.5^{\mathrm{b}}$ \\
\hline (6) & 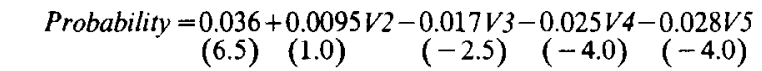 & 769 & $9.0^{\mathrm{b}}$ \\
\hline
\end{tabular}

${ }^{a} C A P E(1,50)$ and $C A P E(1,100)$ are the cumulative daily average prediction errors from 1 day to 50 days, and 1 day to 100 days following the insider trading day, respectively. $L V$ is the natural $\log$ of the average value of equity between 1975 and 1981. $V 2=1$ if value of equity is greater than or equal to $\$ 25$ million and less than $\$ 50$ million, otherwise $V 2=0 . V 3=1$ if value of equity is greater than or equal to $\$ 50$ million and less than $\$ 250$ million, otherwise $V 3=0 . V 4=1$ if value of equity is greater than or equal to $\$ 250$ million and less than $\$ 1$ billion, otherwise $V 4=0 . V 5=1$ if value of equity is greater than or equal to $\$ 1$ billion, otherwise $V 5=0$. Value of equity is less than $\$ 25$ million, if $V 2=V 3=V 4=V 5=0$. Probability is probability of trading against insiders, calculated as the absolute value of the net dollar value of insider trading divided by the total dollar value of trading in that security from 1975 to 1981.

${ }^{\mathrm{b}}$ Significant at $1 \%$ level.

into account by using generalized least squares. The prediction errors across firms at a given calendar day are expected to be uncorrelated, since multiplying the prediction errors for sale transactions by minus one randomizes the prediction errors. ${ }^{10}$

Table 3 shows regression of insiders' abnormal profits on firm size. Models (1) and (3) indicate negative relations between the abnormal returns to insiders and the natural log of the firm size, both significant at the $1 \%$ level. Using the dummy variable models (2) and (4), insiders' abnormal profits in different size firms are readily observable. The cumulative daily average prediction errors from 1 day to 50 days following the insider trading day decrease from $4.5 \%$ to $0.9 \%$ as firm size increases from less than $\$ 25$ million to more than $\$ 1$ billion. Similarly, the cumulative daily average prediction errors from 1 day to 100

\footnotetext{
${ }^{10}$ In addition to the market model, regressions are replicated using the mean-returns adjusted model, Scholes-Williams model, and CAPM. The results are similar and are not shown.
} 
days following the insider trading day decrease from $7.0 \%$ to $1.2 \%$ as firm size increases from less than $\$ 25$ million to more than $\$ 1$ billion. This evidence suggests that, conditional on trading, insiders in small firms earn substantially greater abnormal returns than the insiders in large firms. Consequently, conditional on trading, insiders in small firms also impose substantially greater costs on the uninformed traders than the insiders in large firms.

Table 3 also provides information on the probability of trading against insiders, defined as the ratio of dollar volume of insider trading to all trading in that security. Model (5) in table 3 shows a negative relation between the probability of trading against insiders and the $\log$ of firm size. This relation is significant at the $1 \%$ level. The dummy variable model (6) indicates that the probability of trading against an insider declines from about $4 \%$ for firms less than $\$ 25$ million to about $0.8 \%$ for firms greater than $\$ 1$ billion. Thus, the evidence indicates that the probability of trading against insiders also declines with increasing firm size.

The results in table 3 indicate that the expected losses to insiders fall with the size of the firm. Insiders' abnormal profits, conditional on trading, as well as the probability of trading against insiders decline with the size of the firm. To the extent insider trading is positively correlated with trading by all informed traders, this evidence is consistent with the hypothesis that informed traders impose significant costs on uninformed traders, and the bid-ask spread reflects the expected loss to informed traders.

A precise imputation of the expected loss to informed traders requires measurement of the expected abnormal profits of all informed traders, an empirically infeasible task. This study takes the bid-ask spread for a 100-share transaction as an approximate measure of the expected loss to informed traders. With competition, the bid-ask spread would not differ from the expected loss to informed traders by more than other costs of market-making. For example, if the bid-ask spread were less than the expected loss to informed traders, then the market-maker could not survive. If the bid-ask spread were to exceed the expected loss to informed traders by more than the other costs of market-making, then other potential market-makers would find it profitable to undercut the market-maker by placing simultaneous buy orders at his bid price and sell orders at his ask price.

Market efficiency studies generally assume that informed traders are a negligibly small part of the market, and therefore, the expected loss to informed traders may be ignored. The evidence presented in this study shows a significant positive relation between the bid-ask spread and the expected loss to insiders. This evidence suggests that the expected loss to informed traders is significant and is incorporated into the prices of securities. This finding implies that the expected loss to informed traders must also be taken into account to evaluate the realizable abnormal returns to active trading strategies. An approximate allowance for the expected loss to informed traders can be made 
by including the bid-ask spread as an additional cost of trading. Such an example is Phillips and Smith (1980) who evaluate the efficiency of the listed options market by including the bid-ask spread as an additional cost of trading for active trading strategies.

\subsection{Determinants of insiders' abnormal profits}

Previous insider trading studies have not investigated the sources of insiders' superior predictive ability. Most studies examine intensive trading months, defined as the difference between number of buyers and sellers. Jaffe (1974) also examines large dollar volume of trading by insiders, but concludes that the dollar volume of trading by insiders is not related to the value of insider information. An exception is found by Scholes (1972), who reports differences in the quality of information for different secondary sellers.

The tests presented in tables 4 and 5 investigate the determinants of insiders' superior predictive ability. This investigation also provides a check on the robustness of the negative relation between the expected loss to insiders and firm size. Generalized least squares regressions are used to account for serial correlation of the residuals. The dependent variable is the estimate of insiders' abnormal profit, the cumulative daily average prediction error. The independent variables are dummy variables for sales transactions and types of insiders, dollar volume of insider trading, proportion of firm traded, net number of insiders trading, and value of the firm.

Model (1) in table 4 shows a regression of the cumulative daily average prediction errors from 1 day to 50 days after the insider trading day on a dummy variable for sales transactions. The regression confirms the earlier result that insiders can reliably forecast future abnormal stock price changes, and purchase stock prior to abnormal price increases and sell stock prior to abnormal price decreases. Model (2) shows a regression of cumulative daily average prediction errors on types of insiders. All insiders are grouped into one of five categories: officers, directors, officer-directors, chairmen of the board of directors, and large shareholders. A given month is classified as an officer trading month, if officers trade the most dollar volume during that month. ${ }^{11}$ The coefficient of the officer-director group is significantly positive at the $1 \%$ level, suggesting that on average officer-directors trade on more valuable information than officers. Differences between all insiders are significant at the 5\% level. These tests indicate that insiders who are more familiar with the overall operations of the firm trade on more valuable information.

Model (3) shows a regression of the cumulative daily average prediction errors from 1 day to 50 days after the insider trading day, on the dollar value

\footnotetext{
${ }^{11}$ Similar results are obtained by classifying insider trading months on the basis of the frequency rather than the dollar value of insiders' transactions.
} 
of trading. The slope coefficient in model (3) is insignificantly different from zero, which suggests that the dollar value of insider trading is not related to the value of insider information. This finding is similar to Jaffe (1974) and Scholes (1972) who also fail to find a relation between dollar volume of trading and value of insider information. A likely explanation for this result can be found in tables 1, 3, 4, and 5. Table 1 indicates that insiders in large firms and large shareholders in all firms account for most of the dollar value of trading. Table 3 and model (2) of tables 4 and 5 suggest that insiders in large firms and large shareholders in all firms trade on less valuable information. Consequently, the lack of information content of the large dollar volume transactions is likely to be due to the fact that the large dollar volume of transactions proxies for large firms and large shareholders: Insiders in large firms and large shareholders in all firms who happen to trade the large dollar volume transactions, also trade on less valuable information.

Model (4) in table 4 uses the natural $\log$ of the dollar value of trade. Taking the $\log$ of the dollar value of trade puts relatively less weight on extremely large dollar value transactions. The regression indicates that insiders' abnormal profits increase with the $\log$ of the dollar value of the transactions. The coefficient of the log of dollar value of trading is significantly positive at slightly above the $1 \%$ level. Model (5) uses the natural log of the proportion of the firm traded. Model (5) also indicates a positive relation between the insiders' abnormal profit and the log of proportion of the firm traded which is significant at the 1\% level. Models (4) and (5) suggest that insiders trade larger dollar volume of stock to exploit more valuable information. However, dollar volume of trading increases less than linearly with the value of insider information.

Model (6) uses the natural log of the dollar value of trading and the natural $\log$ of firm size as explanatory variables. The coefficient of the dollar value of trading remains significantly positive, while the coefficient of firm size remains significantly negative. In fact, including firm size increases the significance of the dollar value of trading: For a given firm, insiders respond to more valuable information by trading a greater dollar volume of stock. Model (7) uses the natural $\log$ of the proportion of the firm traded and $\log$ of firm size. Once again, the proportion of the firm traded is positively related to insiders' abnormal profits, while firm size is negatively related to insiders' abnormal profits. Both coefficients are significant at the $1 \%$ level.

Types of insiders are included as additional explanatory variables in models (8) and (9). Inclusion of the types of insiders does not diminish the explanatory power of the firm size or the dollar value of insider trading. The magnitude and the significance of the estimated coefficients for firm size and dollar value of trade agree closely across models (6) and (8). Similarly, the magnitude and the significance of the estimated coefficients for firm size and the proportion of the firm traded agree closely across models (7) and (9). This evidence suggests that 


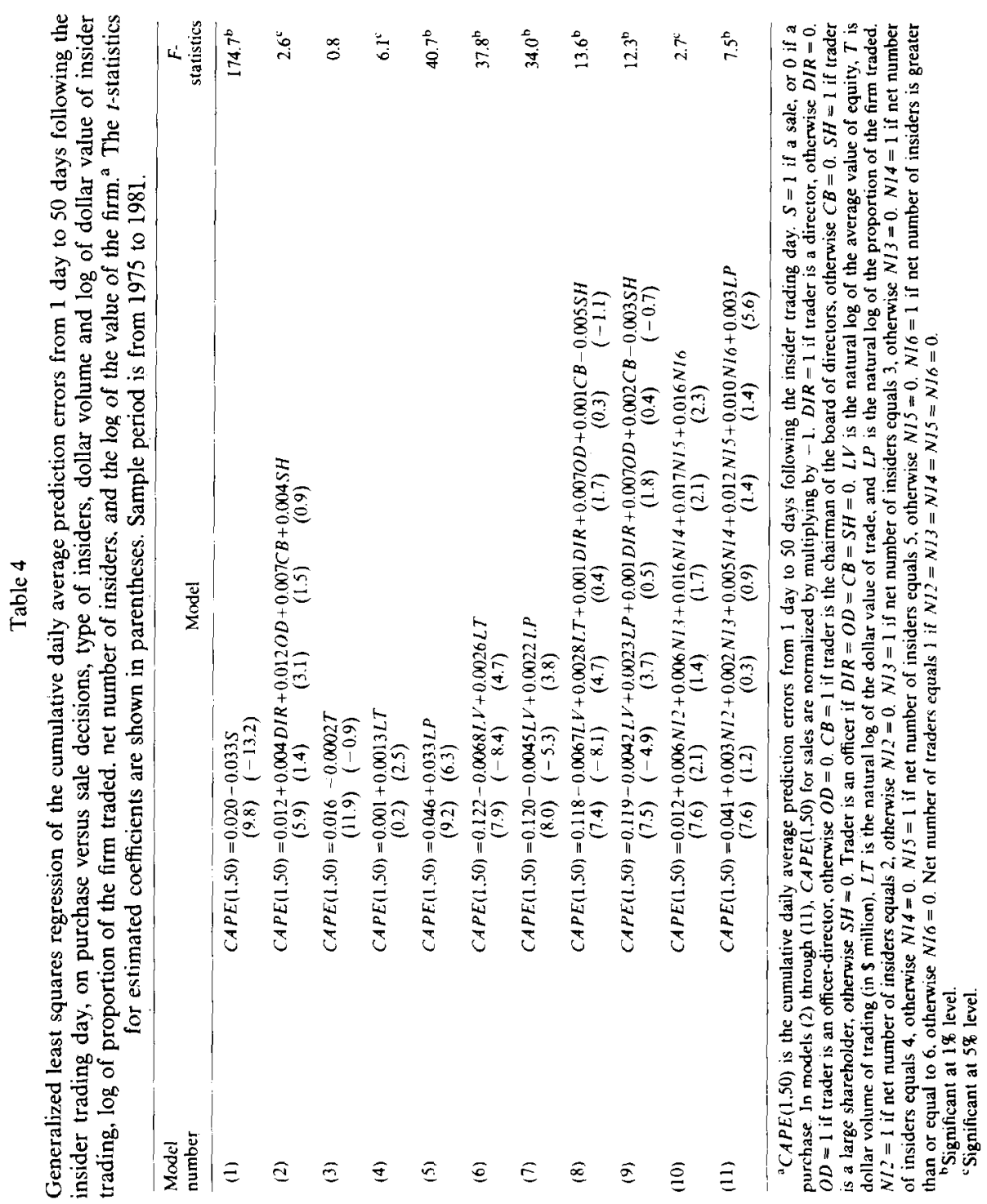




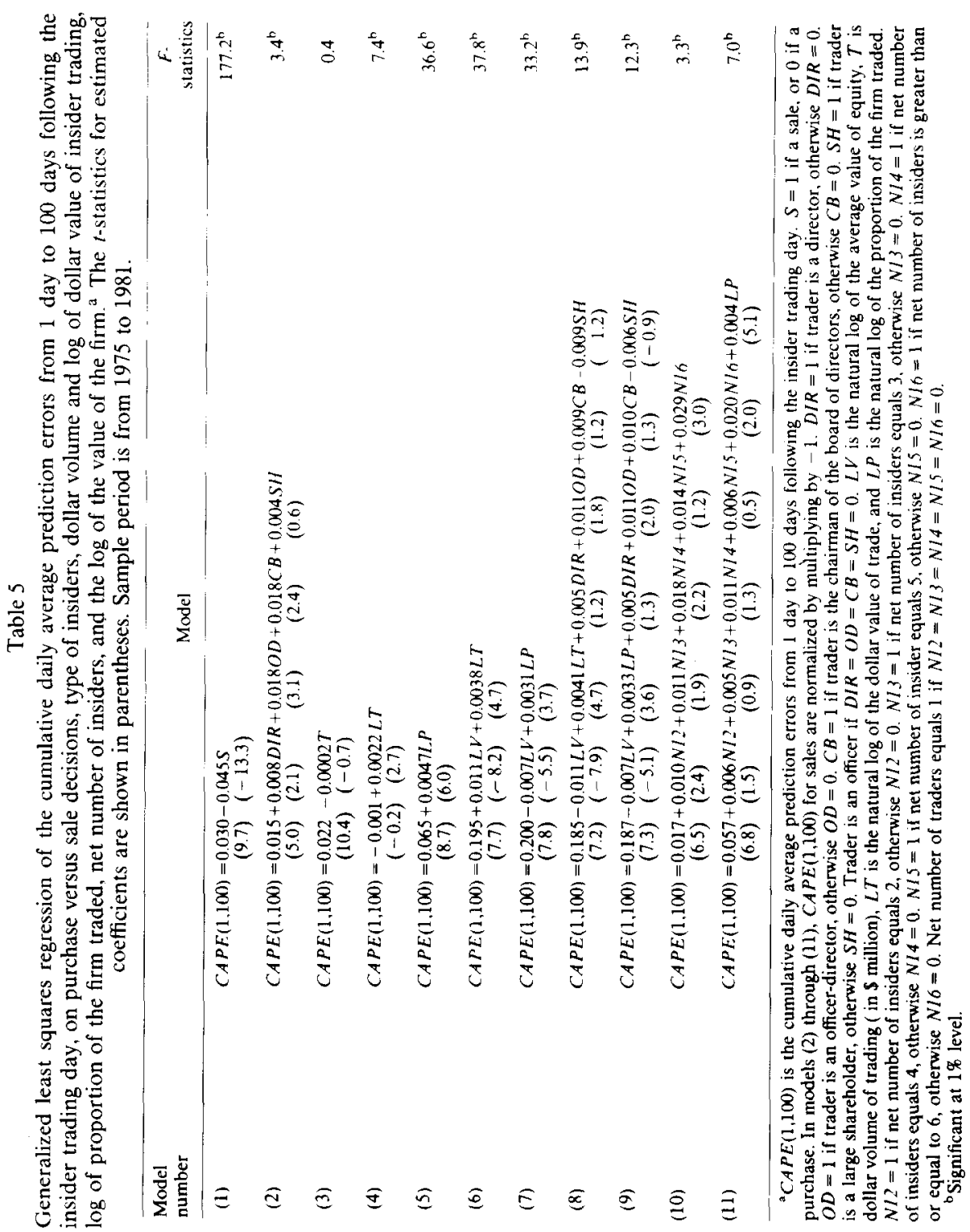


the types of insiders, dollar volume of trading, and firm size are separate determinants of insiders' abnormal profits.

Model (10) shows a regression of insiders' abnormal profits on the net number of insiders, defined as the absolute value of the difference between the number of buyers and sellers. The magnitude of insiders' abnormal profits generally increases with the net number of insiders, and the differences among abnormal returns to the net number of insiders are significant at the $5 \%$ level. This result is similar to a finding by Jaffe (1974). Model (11) also includes the natural $\log$ of the proportion of the firm traded as an additional explanatory variable. Both the coefficient and the significance of the proportion of the firm traded remain unchanged from model (5). However, in model (11), the net number of insiders variable is no longer significant. This evidence suggests that the significance of the net number of insiders is due largely to a proxy effect for the proportion of the firm traded.

The regressions in table 5 use the cumulative average prediction errors from 1 day to 100 days following the insider trading day as a measure of insiders' abnormal profits. The magnitudes of the estimated coefficients in table 5 are somewhat higher than in table 4 while the significance levels of the estimated coefficients are comparable. Differences between table 4 and table 5 are most notable for the identity of insider regression. Model (2) suggests that the chairmen of the boards of directors as well as the officer-directors trade on more valuable information than officers. Differences in abnormal returns to all insiders are significant at the $1 \%$ level in model (2). The other regressions indicate that sales versus purchases, dollar volume of trading, proportion of the firm traded, and firm size remain as significant determinants of insiders' predictive ability. Once again, the significance of the net number of insiders is due largely to a proxy effect for the proportion of the firm traded.

The evidence presented in tables 4 and 5 suggests several conclusions. First, it appears that insider information arises as a result of insiders' association with the firm, since insiders who are closer to day-to-day decision-making trade on more valuable information. Second, the significant negative relation between insiders' abnormal profits and firm size is not diminished when other determinants of insider trading are considered. Most profitable insider trading occurs in small firms. Third, insiders can distinguish the differences in the value of their information and trade a larger volume of stock when they have more valuable information. The failure of the previous insider trading studies to find a positive relation between dollar volume of trading and value of insider information appears to be due to the fact that the large dollar volume of transactions proxies for large firms and large shareholders.

The evidence presented in tables 4 and 5 also provides additional support for the hypothesis that the bid-ask spread reflects the expected loss to informed traders. If the fixed costs of market-making are mostly responsible for determining the bid-ask spreads, then the bid-ask spread is expected to 
Table 6

Insiders' open market transactions from 1975 to 1981 , grouped by the number of calendar days between the insider trading day, the day insiders' reports are first received by the SEC and the availability day of the Official Summary. Numbers in parentheses are the fraction of the total sample of 59,148 transactions.

\begin{tabular}{lcccc}
\hline Event period & $\begin{array}{c}\text { Delay less than } \\
\text { or equal to } 30 \\
\text { days }\end{array}$ & $\begin{array}{c}\text { Delay between } \\
30 \text { and } 60 \\
\text { days }\end{array}$ & $\begin{array}{c}\text { Delay between } \\
60 \text { and } 90 \\
\text { days }\end{array}$ & $\begin{array}{c}\text { Delay over } \\
90 \\
\text { days }\end{array}$ \\
\hline $\begin{array}{l}\text { Trade day to } \\
\text { report day }\end{array}$ & $\begin{array}{c}38,791 \\
(0.66)\end{array}$ & $\begin{array}{c}15,676 \\
(0.27)\end{array}$ & 1,507 & 3,174 \\
$\begin{array}{l}\text { Report day to } \\
\text { availability of }\end{array}$ & 1,389 & 38,246 & 18,560 & $(0.05)$ \\
$\begin{array}{l}\text { Official Summary } \\
\begin{array}{l}\text { Trade day to } \\
\text { availability of }\end{array}\end{array}$ & $(0.02)$ & $(0.65)$ & $(0.31)$ & $(0.02)$ \\
\begin{tabular}{l} 
Official Summary \\
\hline
\end{tabular} & $(0.0)$ & 9,487 & 31,272 & 18,255 \\
& & $(0.16)$ & $(0.53)$ & $(0.31)$ \\
\hline
\end{tabular}

fall with the dollar volume of trade, since a given cost is averaged over a greater number of shares. If the expected loss to informed traders is a significant factor in determining the bid-ask spread, then the bid-ask spread is expected to rise with the dollar volume of trade, since tables 4 and 5 indicate that market-maker's expected loss to informed traders rises with the dollar volume of trade. The available evidence shows that the bid-ask spread indeed rises with the dollar volume of trade. ${ }^{12}$

A word of caution is in order at this point. The coefficients of determination of the regressions shown in tables 4 and 5 are about $1 \%$. This indicates that characteristics of the reported insider transactions explain a small proportion of the variance of abnormal returns. One interpretation of the small coefficient of determination is that insider trading regulations deter insiders from trading freely on the basis of their privileged information. Insiders would have incentive to refrain from trading, or hide their most important information transactions by trading through friends and relatives to avoid potential sanctions by the SEC. Non-reported trading by insiders or trading by informed traders who are not classified as insiders are likely to be more sensitive to the value of their information.

\subsection{Market efficiency}

This study also examines the availability of abnormal profits to outsiders following the first day insiders' reports are received by the Securities and Exchange Commission and the day the Official Summary becomes publicly

\footnotetext{
${ }^{12}$ For example, Mikkelson and Partch (1985) report that the underwriting spread increases with the relative size of the secondary offerings.
} 
Table 7

Percentage cumulative daily average prediction errors and their $t$-statistics in parentheses for 769 firms traded by insiders from 1975 to 1981 around the day insiders' reports are first received by the SEC and the day the Official Summary is available.

\begin{tabular}{|c|c|c|}
\hline \multirow[b]{2}{*}{ Event period } & \multicolumn{2}{|c|}{ Cumulative daily average prediction errors } \\
\hline & $\begin{array}{l}\text { Insiders' reports are } \\
\text { received by SEC; } \\
\text { day } 0 \text { is last day of month }\end{array}$ & $\begin{array}{l}\text { Official Summary is } \\
\text { available on } \\
\text { day } 0\end{array}$ \\
\hline $\begin{array}{l}\text { Day } 1 \\
\text { through } 20\end{array}$ & $\begin{array}{c}0.5 \\
(3.2)\end{array}$ & $\begin{array}{c}0.3 \\
(1.9)\end{array}$ \\
\hline $\begin{array}{l}\text { Day } 1 \\
\text { through } 50\end{array}$ & $\begin{array}{c}0.8 \\
(3.5)\end{array}$ & $\begin{array}{c}0.7 \\
(2.4)\end{array}$ \\
\hline $\begin{array}{l}\text { Day } 1 \\
\text { through } 100\end{array}$ & $\begin{array}{c}1.4 \\
(4.3)\end{array}$ & $\begin{array}{c}1.2 \\
(3.0)\end{array}$ \\
\hline $\begin{array}{l}\text { Day } 1 \\
\text { through } 300\end{array}$ & $\begin{array}{c}1.9 \\
(3.4)\end{array}$ & $\begin{array}{c}1.1 \\
(1.7)\end{array}$ \\
\hline Sample size & 10,221 & 8,302 \\
\hline
\end{tabular}

available. ${ }^{13}$ Table 6 shows that there are substantial delays in reporting and publishing insiders' transactions. For example, the delay between the insider trading day and the availability day of the Official Summary exceeds 90 days for $31 \%$ of the transactions and 60 days for $84 \%$ of the transactions. To prevent biasing the tests against market efficiency, only the reported transactions as of the last day of each month are used to form portfolios. Similarly, for the publication day tests, only the published transactions in the Official Summary are used to form portfolios for any calendar month.

Table 7 shows the cumulative daily average prediction errors for selected periods around the day insider reports are received by the SEC and the availability day of the Official Summary. The cumulative daily average prediction errors are also plotted in fig. 2. The methodology used to measure the magnitude and significance of the cumulative daily average prediction errors is identical to the trading day tests. Table 7 indicates that if an outsider trades on the basis of insiders' transactions as soon as insiders' reports are received by the SEC, he can earn $1.4 \%$ after 100 days and $1.9 \%$ after 300 days. If the outsider waits until after the Official Summary is available, then the gross abnormal return is only $1.1 \%$ during the next 300 days. Fig. 2 indicates that the decline in abnormal return following the dissemination of insider trading

\footnotetext{
${ }^{13}$ Since no publication dates appear on the Official Summary, the date the Official Summary is received by the Rush-Rhees Library of the University of Rochester is used as the availability date. Due to delays in postal delivery, the actual availability date may be as much as a week to ten days earlier than the delivery date to the Rush-Rhees Library.
} 

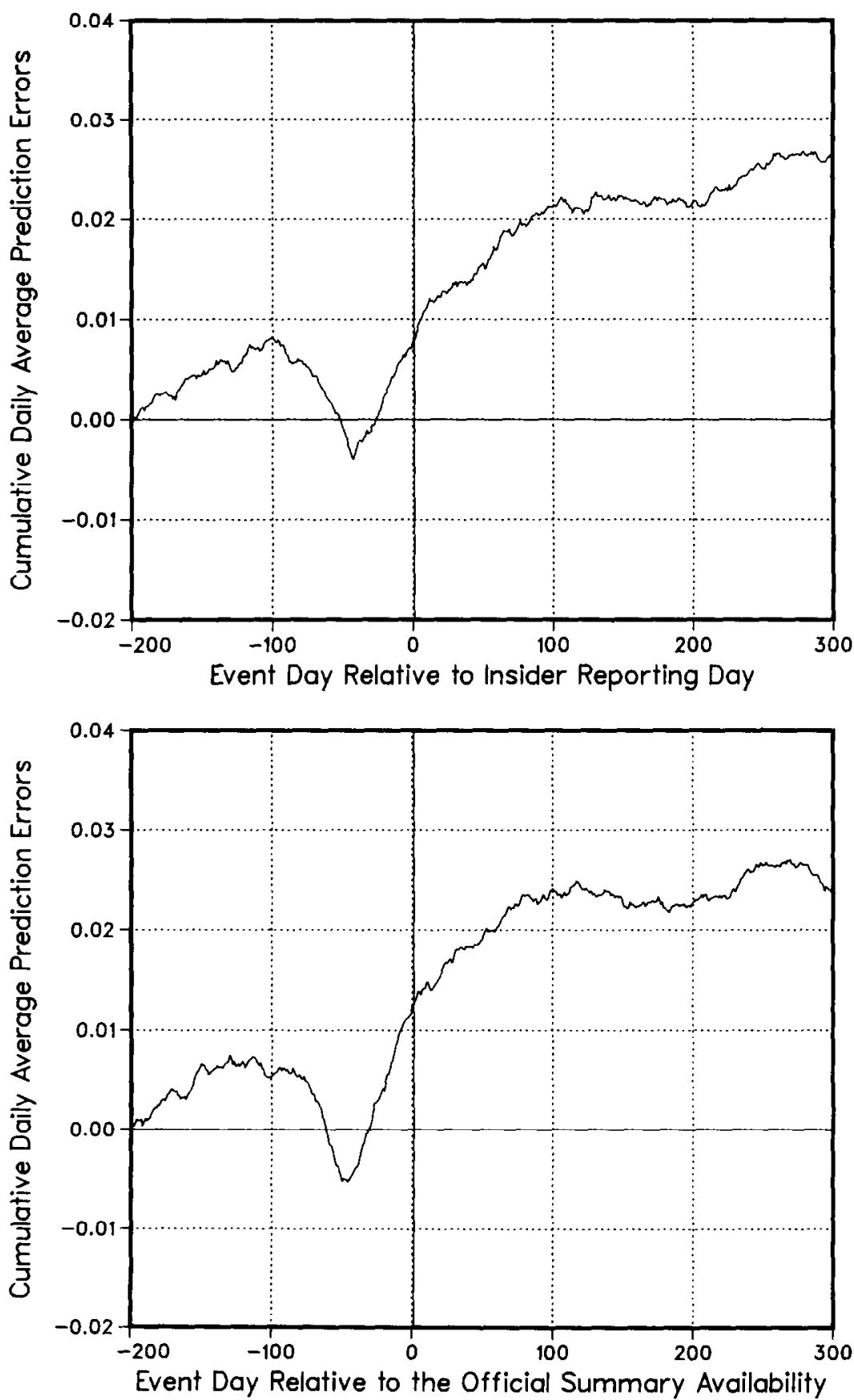

Fig. 2. Cumulative daily average prediction errors from 199 days before to 300 days after the first day insiders' reports are received by the SEC and the availability day of the Official Summany to a portfolio of 769 firms traded by insiders during 1975 to 1981 . 
information is attributable to the stock price adjustment following the insider trading day.

To evaluate the realizable abnormal profits from imitating insiders, outsiders' gross abnormal profits are compared to the bid-ask spread for 100-shares plus the commission fee for a round trip transaction. The bid-ask spread plus the commission fee is taken to be $6.8 \%$ for firms less than $\$ 25$ million, $5.2 \%$ for firms between $\$ 25$ and $\$ 50$ million, 3.7\% for firms between $\$ 50$ and $\$ 250$ million, 3.2\% for firms between $\$ 250$ million and $\$ 1$ billion, and $2.7 \%$ for firms greater than $\$ 1$ billion. ${ }^{14}$ Net of these trading costs, abnormal returns to outsiders following either the reporting day or the publication day are nonpositive. In addition, abnormal profits to outsiders using more selective trading rules based on identity of insiders, dollar volume of trading, proportion of the firm traded, and firm size are examined. More selective trading rules also reveal no significantly positive abnormal profits to outsiders net of the trading costs. This evidence is consistent with market efficiency. Insiders can predict future abnormal stock price changes, however, following the public dissemination of insider trading information, outsiders cannot earn abnormal profits net of trading costs.

\section{Conclusions and implications}

The evidence presented in this study indicates that insiders can predict abnormal future stock price changes. Insiders purchase stock prior to an abnormal rise in stock prices and sell stock prior to an abnormal decline in stock prices. Furthermore, different insiders possess differences in quality of information. Insiders who are expected to be more knowledgeable with the overall affairs of the firm, such as chairmen of the boards of directors or officer-directors, are more successful predictors of future abnormal stock price changes than officers or shareholders alone. Evidence also suggests that insiders can discern the differences in the value of their information and trade greater volumes of stock to exploit more valuable information.

The evidence presented in this study also shows that as a percentage of stock price, the expected loss to insiders and firm size are negatively correlated. This finding is consistent with the hypothesis that the expected loss to informed traders is reflected in the bid-ask spread for a given security, since smaller firms have larger percentage bid-ask spreads. An implication of this evidence is that ignoring the expected loss to informed traders, especially in small firms, can lead to an overstatement of the realizable abnormal return to any active trading strategy. An allowance for the expected loss to informed traders can be

\footnotetext{
${ }^{14}$ Estimates of trading costs correspond 10 Stoll and Whaley estimates for their firm size groups 1, 2, 6, 9, and 10. See Stoll and Whaley (1983, p. 73).
} 
made by deducting the bid-ask spread from the gross abnormal return to any active trading strategy. This evidence also suggests that some recent anomalies concerning the efficient markets hypothesis can disappear if the expected loss to informed traders is taken into account by including the bid-ask spread as an additional cost of trading.

In this study, the realizable return to outsiders is examined following the first day insiders' reports are received by the SEC and the day the Official Summary becomes publicly available. Following the public dissemination of insider trading information, the abnormal return to outsiders net of the bid-ask spread plus the commission fee is non-positive. Examining more selective trading rules based on types of insiders, dollar volume of trading, proportion of the firm traded, and firm size also shows that no significantly positive abnormal return to outsiders net of the trading costs. This evidence is consistent with market efficiency: Outside investors cannot use the publicly available information about insiders' transactions to earn abnormal profits.

\section{References}

Amihud, Y. and H. Mendelson, 1980, Dealership market: Market making with inventory, Journal of Financial Economics 8, 31-53.

Bagehot, W. (pseud), 1971, The only game in town, Financial Analyst Journal 2, 12-14

Banz. R.W.. 1981. The relationship between return and market value of common stocks, Journal of Financial Economics 9, 3-18.

Benston, G.J. and R.L. Hagerman, 1974, Determinants of bid-asked spreads in over-the-counter market, Journal of Financial Economics 1, 353-374.

Copeland, T.E. and D. Galai, 1983, Information effects on the bid ask spread, Journal of Finance $38,1457-1470$.

Demsetz, H., 1968, The cost of transacting, Quarterly Journal of Economics 82, 33-53.

Fama, E.F., 1970, Efficient capital markets: A review of theory and empirical work, Journal of Finance 25, 383-417.

Fama, E.F., 1976, Foundation of finance (Basic Books, New York).

Fama, E.F., L. Fisher, M.C. Jensen and R. Roll, 1969, The adjustment of stock prices to new information, International Economic Review 10, 1-21.

Finnerty, J.E., 1976, Insiders and market efficiency, Journal of Finance 31, 1141-1148.

Glosten, L.L. and P.R. Milgrom, 1985, Bid, ask and transaction prices in a specialist market with heterogeneously informed traders, Journal of Financial Economics 14, 71-100.

Jaffe, J.F., 1974, Special information and insider trading, Journal of Business 47, 410-428.

Lorie, J.H. and V. Niederhoffer, 1968, Predictive and statistical properties of insider trading, Journal of Law and Economics 11, 35-51.

Mikkelson, W.H. and M.M. Partch, 1985, Stock price effects and costs of secondary distributions, Joumal of Financial Economics 14, 165-194.

Nelson, C.R., 1973, Applied time series analysis (Holden-Day, San Francisco, CA).

Phillips, S.M. and C.W. Smith, Jr., 1980, Trading costs for listed options: The implications for market efficiency, Journal of Financial Economics 8, 179-201.

Pratt, S.P. and C.W. DeVere, 1970, Relationship between insider trading and rates of return for NYSE common stocks, 1960-1966, in: J. Lorie and R. Brealey, eds., Modern developments in investment management (Praeger, New York).

Reinganum. M.R., 1981, Misspecification of capital asset pricing: Empirical anomalies based on earnings' yields and market values, Journal of Financial Economics 9, 19-46. 
Scholes, M.S., 1972, The market for securities: Substitution versus price pressure and the effects of information on share price, Journal of Business 45, 179-211.

Scholes, M.S. and J. Williams, 1977, Estimating betas from non-synchronous data, Journal of Financial Economics 5, 309-328.

Schultz, P., 1983, Transactions costs and the small firm effect: A comment, Journal of Financial Economics 12, 81-88.

Stoll, H.R., 1978, The supply of dealer services in securities markets, Journal of Finance 33, 1133-1151.

Stoll, H.R. and R.E. Whaley, 1983, Transactions costs and the small firm effect, Journal of Financial Economics 12, 57-79.

Tinic, S.M., 1972, The economics of liquidity services, Quarterly Journal of Economics 86, 79-93.

Tinic, S.M. and R.R. West, 1972, Competition and the pricing of dealer service in the over-thecounter stock market, Journal of Financial and Quantitative Analysts 7, 1707-1728.

Treynor, J., 1981, What does it take to win the trading game?, Financial Analysts Journal, 55-60. 